\title{
1. Introduction: the double dualization of inequality in Europe
}

Martin Heidenreich

\subsection{HORIZONTAL EUROPEANIZATION AND THE EUROZONE CRISIS: TWO DETERMINANTS OF THE EUROPEANIZATION OF SOCIAL INEQUALITY}

The process of European integration is being increasingly faced with the need to ensure the social integration of Europe's citizens. Until the 1980s, the crises afflicting the European integration project mainly concerned the relationship between sovereign nation-states and supranational institutions and policies. During the more recent crises surrounding the Maastricht Treaty (1993), the European Constitutional Treaty rejected by the French and Dutch populations in 2005, the current financial, economic and sovereign debt crisis which began in 2008 (Giddens 2014) and the migration and refugee crisis since 2015, the relationship between European citizens and the protagonists of the European integration project both at the national and the European level has become central (Fligstein 2008). The long-standing permissive consensus among Europeans, which for decades enabled the deepening and enlargement of the European Union (EU) in an expertocratic, elite-driven way, is gradually eroding (Hooghe and Marks 2009). The EU is evolving from an intergovernmental arena into a social space characterized by closer interdependencies between European citizens. This is not only a result of geographic proximity and a partly common, conflict-ridden history, but it is mainly the result of the common political, legal, economic, monetary and social framework which has liberalized European markets, facilitated cross-border mobility and created a common currency for, currently, 19 of the 28 EU Member States. Therefore, it is not surprising that Europeans are increasingly aware of the impact of European political institutions, processes and decisions on their living conditions.

This growing awareness of the supra- and transnational influences on living conditions has been reinforced by the sovereign debt crisis in the 
eurozone. Beginning as a global financial crisis in 2008, this crisis turned into a sovereign debt crisis in 2010 and led to the erosion of trust in EU institutions and other EU Member States (Armingeon and Ceka 2013; Braun and Tausendpfund 2014). It also gave rise to Eurosceptic and populist parties in many European countries, bitter conflicts concerning the regulation of the euro area and the financing of bailout programmes, and the possibility of some countries leaving the eurozone or even the EU.

The starting point of this volume is the assumption that the erosion of trust in the EU, the euro and other EU Member States is the outcome of these two processes, namely horizontal Europeanization and the sovereign debt crisis. Firstly, social inequalities are increasingly perceived in a European context. Europeans compare their living situation not only with their compatriots, but also with other Europeans. This reflects the increasing economic interdependencies, cross-border relations and crossborder networks in the EU (cf. Mau and Mewes 2012). Europeans with more cross-border relations have better opportunities for coping with unemployment, financial difficulties and other biographical challenges (Chapter 8). These processes of horizontal Europeanization, but also the impact of EU policies on national policies (cf. Featherstone and Radaelli 2003), are reflected in increasingly transnational perceptions of social inequalities. This has been termed the Europeanization of social inequalities.

Secondly, the erosion of trust in the EU is also the result of the financial, economic and sovereign debt crisis in Europe that has affected European economies since 2008 and that has not yet ended, as shown by the debates on a third bailout programme for Greece in 2015 and the still deficient institutionalization of the euro. This crisis has led to an unprecedented level of institutionalized solidarity among the EU Member States (as indicated by the financial volume of the bailout funds ESM (European Stability Mechanism), EFSM (European Financial Stability Mechanism) and EFSF (European Financial Stability Facility); cf. Chapter 9), but also to very different impacts on the living conditions of Europeans and a serious deterioration in the social situation, particularly in Southern Europe. This can be illustrated by two selected indicators which refer to the individual and the household level - unemployment (Figures 1.1 and 1.2) and deprivation (Figures 1.3 and 1.4). Figures 1.1 and 1.3 are based on national means which have been aggregated by common European country groups in order to illustrate different trajectories in Europe. These figures especially highlight the split between Scandinavian and Continental European countries on one side and the Eastern and Southern European countries on the other side. In addition, they also illustrate the deterioration of employment and living conditions in Southern Europe in relation to Eastern Europe. This shows the reorganization of centre-periphery 


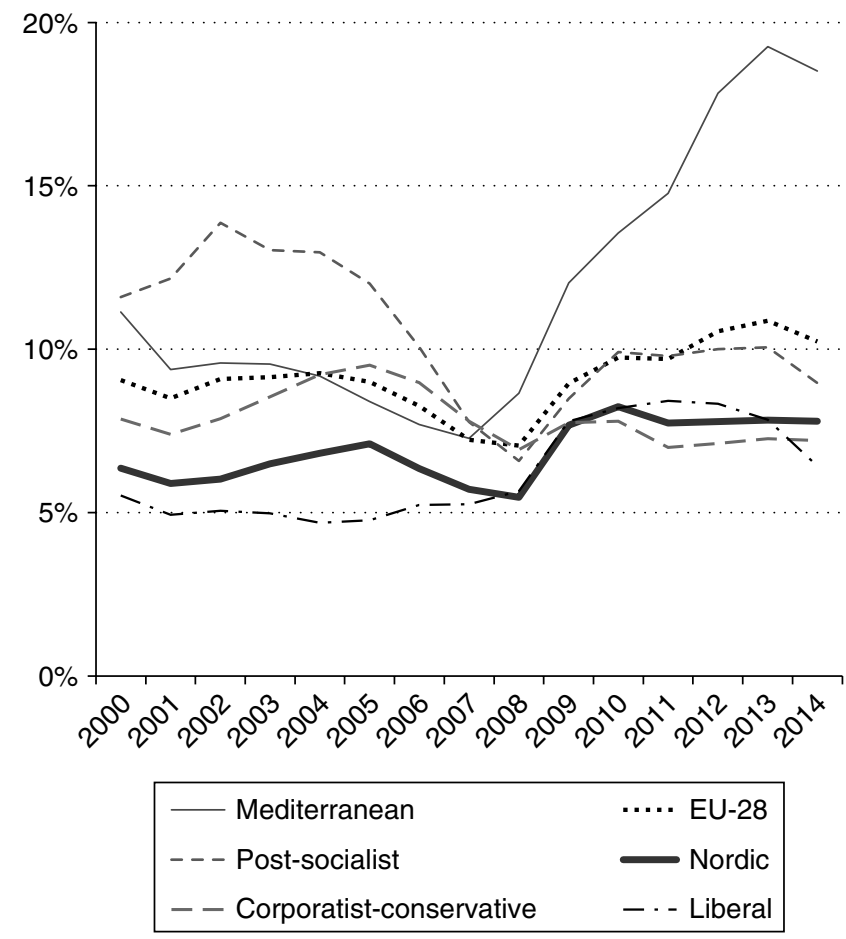

Note: The average national unemployment rates for the five employment regimes (cf. Gallie and Paugam 2000) are weighted by the respective labour force. The countries have been grouped as follows: Liberal: UK, IE; corporatist: NL, LU, FR, DE, BE, AT; Mediterranean: PT, MT, IT, ES, EL, CY; post-socialist: RO, SK, SI, PL, LV, LT, HU, EE, CZ, BG; Scandinavian: DK, SE, FI. The differences between the regimes are highly significant.

Source: Own calculations based on Eurostat, table [une_rt_a].

Figure 1.1 Regime-specific unemployment rates in the EU-28 (2000-2014)

relations in Europe and the restructuring of the European periphery during the eurozone crisis.

Besides these territorial separation lines, the European population is also socially divided. Figures 1.2 and 1.4 illustrate that Europeans are affected differently by unemployment and deprivation according to their age, gender, migration background and educational levels. Apart from the territorial cleavages which dominate public discourse, the EU is also a social space. Younger persons with a lower education and a migration 


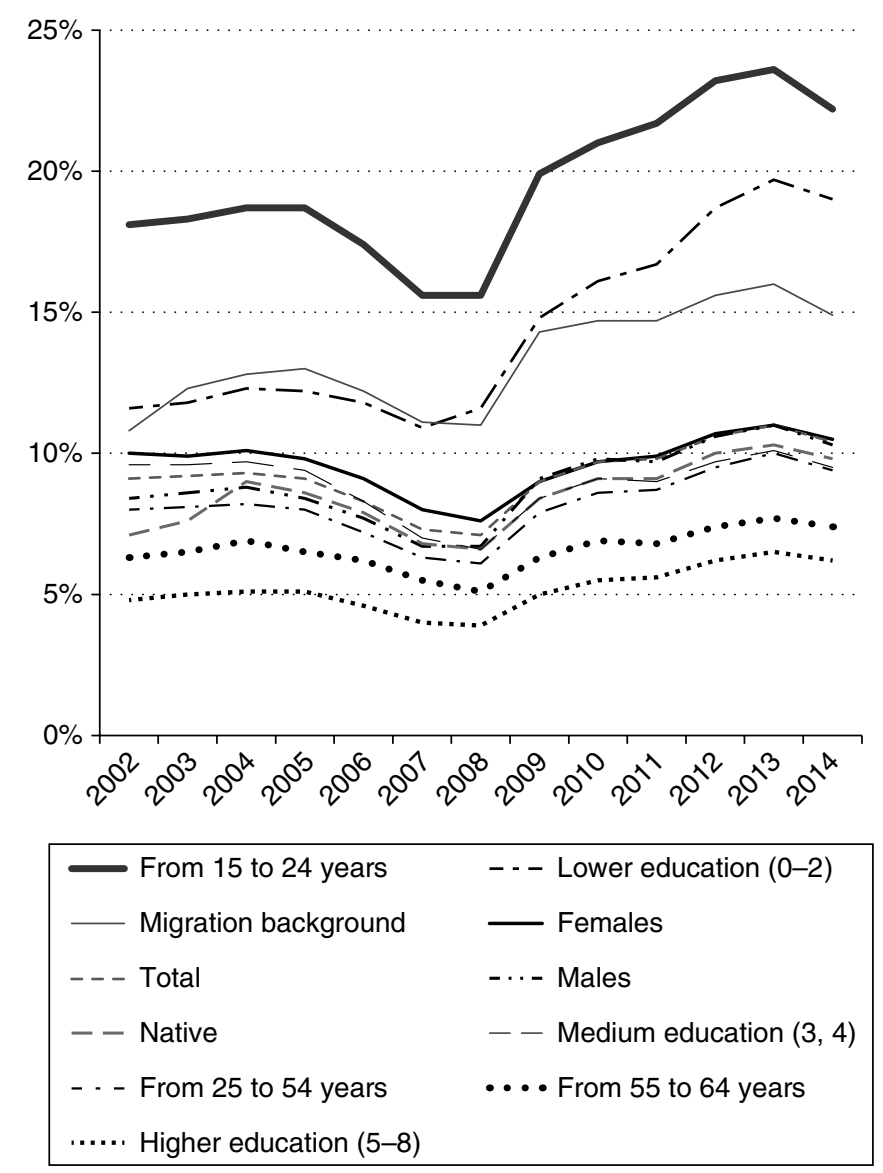

Source: Eurostat, tables [lfsa_urgaed] and [lfsa_urgacob]. The educational levels refer to the ISCED classification.

\section{Figure 1.2 Unemployment rates by socio-demographic background} (EU-28; 2002-2014)

background suffer on average much more from unemployment and deprivation than highly educated, older natives - and these negative effects have become more pronounced since the crisis.

The objection could be raised that the Mediterranean or corporatistconservative countries or older and younger persons are not homogeneous and that the previously mentioned territorial and social characteristics interact: the situation of a young Spaniard is much worse than a German 


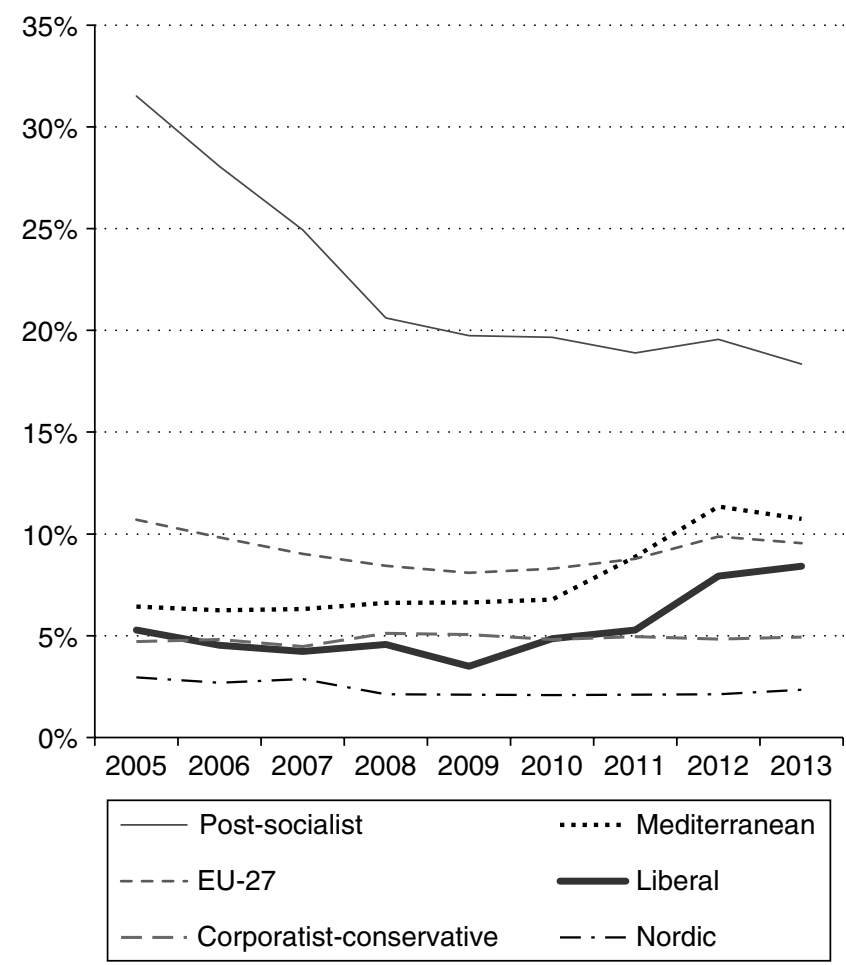

Note: The severe material deprivation rate measures the percentage of the population that cannot afford at least four of the following items: (1) to pay their rent, mortgage or utility bills; (2) to keep their home adequately warm; (3) to face unexpected expenses; (4) to eat meat or proteins regularly; (5) to go on holiday; (6) a television set; (7) a washing machine; (8) a car; (9) a telephone. See Figure 1.1.

Source: Own calculations on the basis of Eurostat, table [ilc_mddd21].

\section{Figure 1.3 Severe material deprivation in different EU regions (EU-27;} 2005-2013)

of the same age. This is the reason why we test our arguments in the following chapters on the basis of micro-data using multivariate methods. In order to grasp the multidimensionality of inequality, we use various indicators which refer either to the individual (in the case of unemployment, but also in the case of long-term unemployment, temporary employment or wage levels) or to household-related living conditions (in the case of deprivation, but also in the case of poverty).

A major result of our analyses, which is also illustrated by the previously 


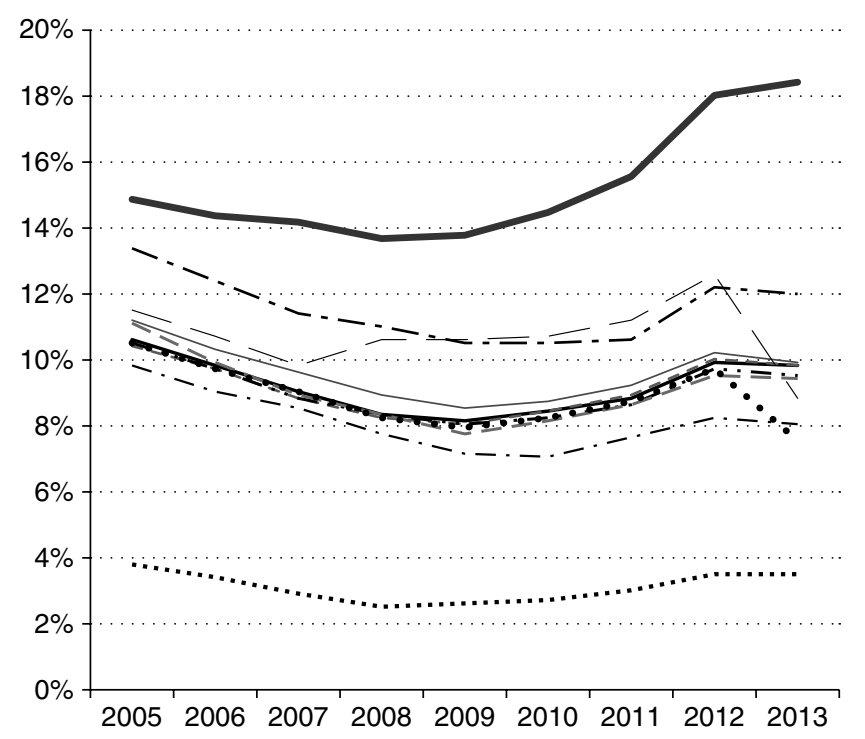

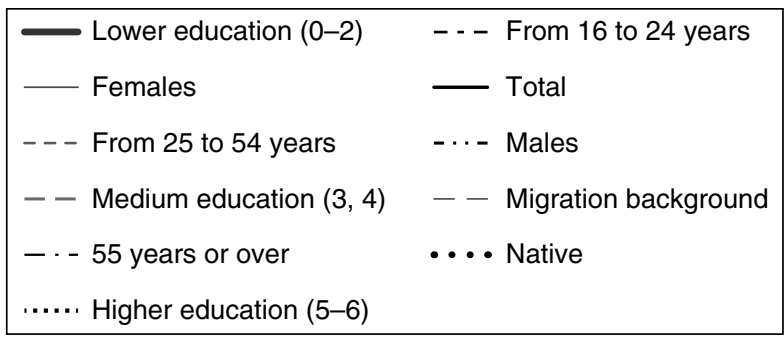

Source: See Figure 1.3. Eurostat, tables [ilc_mddd11], [ilc_mddd21]. [ilc_mddd14] and [ilc_mddd16].

Figure 1.4 Severe material deprivation by socio-economic background (EU-27; 2005-2013)

discussed four figures, is the double dualization thesis: the living situations of Europeans are divided along territorial and social or socio-demographic lines (Mau et al. 2012). On the one hand, after a decade of prosperity and convergence, the eurozone crisis has contributed to an increasing dualization of life chances, especially between Northern and Southern Europeans. On the other hand, life chances are diverging between younger and older, migrant and native, male and female, and high- and low-skilled employees. The following chapters show that this double dualization can be observed 
not only for the two indicators taken here as an illustrative example, but also for other dimensions of social inequality: income inequality and subjective socio-economic insecurity (Chapter 2), persistent poverty (Chapter 3), long-term unemployment (Chapter 4), low pay (Chapter 5), temporary contracts (Chapter 6), unmet medical needs (Chapter 7) and life satisfaction (Chapter 8).

From a sociological perspective, the institutionalization of these territorial and social cleavages differs fundamentally between a nation-state or other forms of a political union and a loose intergovernmental association of sovereign states. While a nation-state tries to replace territorial cleavages with social cleavages (in order to avoid irreconcilable conflicts between different ideologies or regional identities which favour separatist movements; Heidenreich 2003), an intergovernmental association is characterized by bargaining relations between different nations which aggregate and articulate the interests of their citizens. Between these two opposite forms of interest aggregation, three different forms of conceiving the Europeanization of social inequalities can be distinguished. This will be discussed in the next section (1.2). In order to introduce the following analyses, major results will be discussed in a comparative perspective in section 1.3. In the last section, these chapters are briefly summarized (1.4).

\subsection{BEYOND THE METHODOLOGICAL NATIONALISM OF INEQUALITY RESEARCH: THREE VARIANTS OF THE EUROPEANIZATION THESIS}

Social inequalities have been analysed so far almost exclusively in the national context, or from an internationally comparative perspective (Alderson and Nielsen 2002; Wilkinson and Pickett 2009; OECD 2015). There are compelling reasons for such a national frame of reference. Since the end of the nineteenth century, at least in Europe, the national welfare state has become the central guarantor of social security (Castles et al. 2010). Even in a globalized world, the perception and articulation of social risks and inequalities as well as attempts by the public to reduce them take place largely at the national level. Nation-states are the largest known levels on which norms of equality and solidarity are effectively institutionalized. Social security benefits and taxes, unions and wage bargaining systems, education and training, public systems of interregional redistribution - all these institutions are mainly institutionalized at the national level. This was especially the case in the post-war period of egalitarian capitalism, which was characterized by relatively closed national economies, national 
wage-bargaining and educational systems, and by national welfare states (Kenworthy 2004). These observations have formed the basis of the 'methodological nationalism' of inequality research, i.e. the assumption that nation-states are the natural unit of analysis for patterns of social inequality due to the congruence of territorial, political, economic and social borders and cognitive frames of perception (Smith 1983: 26; Beck 2007). In a world dominated by nation-states, culturally homogeneous democratic welfare states have been the primary focus of requests for civil, democratic and social rights (Rokkan 1999).

However, despite the predominantly national framework of analysis, supra- and transnational developments also shape the distribution of income and the living opportunities of people. The rise in national inequalities, but also the decline of between-nation inequalities, has been explained by the globalization of goods, services, labour and capital markets (Alderson and Nielsen 2002; OECD 2011; Milanovic 2013), and by skill-biased technological change, i.e. by the increasingly important role of specific qualifications and skills in the context of global technological competition.

In addition to global trends, the EU has also become an essential unit for the generation and regulation of inequalities (Beckfield 2006; Fligstein 2008; Heidenreich 2003). At least until recently, the economic, monetary and legislative integration and regulatory harmonization in Europe has led to a convergence of the standards of living in the EU. Since the Great Recession (2008-2009) and the subsequent sovereign debt crisis in Europe (2010-2015), however, the negative effects of an incomplete monetary union have also become obvious. The necessity of adapting employment and wage levels instead of devaluating the own national currency euro and the European-wide limits for sovereign debts have led to restrictive public policies, more generally termed as austerity policies (Blyth 2013)

This demonstrates the need for inequality research to overcome the 'methodological nationalism' of inequality research by taking into account the multiple geographical references of social inequality in a multiscalar perspective, analysing inequalities as the outcome of socio-spatial processes which take place in distinct spatial units (Brenner 2001: 604), for example the regions, the nation-states and the EU.

In such a multiscalar context, this book claims that we are witnessing a Europeanization of social inequalities. This concept 'refers to transnational processes caused by the European integration, which shape the distribution of scarce and desired goods and positions thus shaping the life chances, the social identities, the interests and values of individuals and social groups' (Heidenreich and Wunder 2008: 33). This concept highlights both the objective dimension of social inequalities, which is the European 
impact on the distribution of resources and positions, and its subjective dimension, namely the transnationalization of the reference groups and standards of equality. It claims that social differences between autonomous EU Member States are no longer merely evaluated as social disparities in unrelated social spheres, but as social inequalities in a common social space characterized by transnational frames of reference and by conflicts between transnational social groups regarding privileged access to more or less advantageous social positions and resources. The social and economic heterogeneity of Europe, which for centuries was contained in closed nation-states (Rokkan 1999), is returning to the fore. This concept can be understood in at least three different ways (see Chapter 2 for the case of income inequalities). Firstly, as an indicator of the growing importance of Europe for the analysis and comparison of national inequalities; secondly, as a reference to the growing importance of European and more specifically EU-related factors which influence patterns of social inequality; and, thirdly, as a reference to transnational frames of references. This analytical separation is loosely inspired by the classical distinction made by Geiger (1932) between the description of the unequal distributions of social resources and relations (Lagerungsbild), its explanation by different, often class-related, strategies and dynamics (Schichtungsbild), and the subjective perceptions, mentalities and lifestyles of the individuals (Mentalitätsbild).

In the first perspective, which is still firmly rooted in the methodological nationalism of inequality research, Europe is conceived as an international social space, in which the patterns and developments of within-state inequality can be compared and the evolution of total and between-state inequality can be analysed - for example, the divergence or convergence of individual standards of living or the increasing or decreasing share of between-state inequality. In this perspective, the nation-state is still the main point of reference for the diagnosis of equality and inequality. Inequality indices therefore reflect the distribution of socially valuable goods and opportunities among the population of a specific country. Here, Europeanization refers to the increasing importance of Europe as a point of reference for the comparison of national patterns of inequality: '(T)he more Europeanization there is, the more the principle of comparability replaces the principle of the incomparability of social inequality between nation state spaces' (Beck 2007: 695). In contrast to the third concept, in which the people in the involved countries also compare their living situations with persons in other countries, these comparisons are limited to the scientific sphere. The standards of equality of the respective individuals still refer to national reference groups. Between EU Member States, territorial cleavages are dominant.

In the second perspective, the Europeanization of social inequalities 
refers to the economic, political and monetary integration of Europe and its impact on life chances. This is close to the usage of the term in political science in which Europeanization refers to the

(p)rocesses of (a) construction (b) diffusion and (c) institutionalisation of formal and informal rules, procedures, policy paradigms, styles, 'ways of doing things' and shared beliefs and norms which are first defined and consolidated in the making of EU decisions and then incorporated in the logic of domestic discourse, identities, political structures and public policies. (Radaelli 2003: 30)

This definition conceives of the EU as a supranational political and administrative space, and focuses on its impact on political changes in the national arena. Examples of the impact of European policies on the social and income situation of the population are the influence of the common market on economic growth and income (Fligstein and Stone Sweet 2002), the impact of the political and legal integration of Europe on living conditions (cf. Beckfield 2009) and the impact of a common currency and the recently strengthened eurozone-wide coordination of national economic policies on standards of living (Blyth 2013). In this case, territorial cleavages are still dominant, but EU-wide policies may provide social rights to selected social groups (e.g. to farmers, workers, women, students, transnationally mobile EU citizens).

In the third understanding, the Europeanization of social inequalities refers to the increasing relevance of transnational norms, standards of equality and frames of reference (Delhey and Kohler 2006; Fahey 2007; Kangas and Ritakallio 2007). Whelan and Maître (2009: 118) distinguish between a weak and a strong version of this argument: 'The former proposes that a common standard relating to an acceptable level of participation in one's own society emerges as a consequence of knowledge of conditions in other societies (...) The stronger version requires (...), that people perceive themselves as part of a larger European stratification system.' Besides territorially conceived interests, cleavages between different social groups cutting across national lines become more important for example between winners and losers of Europeanization processes (Fligstein 2008). Other indicators of the emergence of transnational standards of evaluation are the generally lower life satisfaction in poorer EU countries (Chapter 2) and the surprisingly high level of declared solidarity between EU citizens (Gerhards and Lengfeld 2015).

In a perspective inspired by Rokkan (1999), these forms of Europeanization can be seen as indicators that, in addition to territorial cleavages between different European nations, socio-economic cleavages between advantaged and disadvantaged social groups become more important. An international or supranational Europe becomes a European 
societal sphere. An international Europe is dominated by conflicts between central and peripheral regions and countries; it can be integrated by intergovernmental negotiations and agreements, as liberal intergovernmentalism has taught us (Moravcsik 1998). In a supranational Europe analysed by neofunctional approaches, economic and political interdependencies require common rules which are developed and monitored by supranational institutions such as the European Commission or the European Court of Justice. In both cases, interests are conceived first of all in a national perspective. A transnational conception transcends such a territorial definition of identities, norms of equality, interests, and conflicts, focusing instead on the living situations, practices, interests and perceptions of transnational social groups defined for example by age, gender, education, migration experiences, occupation, lifestyle or mobility. Conflicts and bargaining processes also emerge along social lines and not only territorial lines. This would undermine the exclusive responsibility of the nation-state regarding the definition and articulation of social interests. Its emergence would imply that European integration and growing cross-border transactions and interdependencies between Europeans would lead to a partial 'unfreezing' of nationally defined interests (Ferrera 2003). The EU would become a contested terrain for issues which were previously the exclusive domain of the nation-state and which are now also the sphere of competing civil society actors, trade unions, business associations and other interest groups. Conflicts in Europe would not only be conflicts between central and peripheral countries and regions, but also between 'winners' and 'losers' of Europeanization processes (Kriesi et al. 2006). Even if such a European societal sphere seems a very distant vision, the aforementioned results on the Europeanization of solidarity in the EU and indicators of the third understanding of the Europeanization of social inequalities might indicate that the eurozone crisis might contain the possibility of transcending the mostly territorial cleavages of the EU.

In sum, the Europeanization thesis comprises the concept of comparing national inequality patterns in a European context (international perspective), the concept of explaining the patterns and dynamics of social inequalities in terms of the supranational regulation of the European economies and societies, and the concept of the emergence of transnational standards of equality and frames of reference. These three concepts refer to different causal mechanisms. In the first case, Europeanization is the result of spatial and historical proximity and some basic similarities (e.g. as highly industrialized or knowledge-based countries with an advanced welfare state and a democratic order) which allow for comparison. In the second case, the drivers of Europeanization processes are EU policies such as the abolishment of internal border controls or the introduction 
of a common European currency. In the third case, the causal factors are increasing cross-border contacts, networks, debates, transactions and transnational social conflicts between different socio-economic groups.

\subsection{SOCIAL INEQUALITIES IN THE EUROZONE CRISIS: FIVE TRENDS}

A major reason for the Europeanization of social inequalities, especially during the period of time that we analyse in this volume, is the introduction of the euro in, currently, 19 EU Member States. This currency union is characterized by a discrepancy between the Europeanized monetary policy and the still national fiscal policies. At the EU or eurozone level no political authority exists with sufficient financial capacity to deal with the three challenges of a currency union (Shambaugh 2012; De Grauwe 2014): (1) the illiquidity of Member States due to excessive public debts; (2) the illiquidity of banks due to excessive private debts; (3) cyclical economic downturns. The first challenge would require either a regime for dealing with insolvent states, Europe-wide bailout funds or a central bank which functions as the lender of last resort; the second challenge requires a banking union which also includes a common responsibility for the resolution of heavily indebted banks; and the third challenge requires an anti-cyclical fiscal policy at the eurozone level (for example, automatic stabilizers as a European unemployment insurance).

Given the absence of such a Europe-wide fiscal capacity, Friedman (1997) predicted early on that the introduction of the euro 'would exacerbate political tensions by converting divergent shocks that could have been readily accommodated by exchange rate changes into divisive political issues'. The essential question is which adjustment mechanisms can buffer the effects of economic shocks after the abolition of flexible exchange rates. While flexible exchange rates allow a quick adaptation of nominal wages and prices by means of a devaluation, such an adaptation in a currency union requires either high cross-border mobility, high international transfer payments, increasing public debts, a flexible labour market that allows productivity increases by closing down unproductive businesses, or flexible nominal wages in order to compensate for the loss of flexible exchange rates. In the eurozone crisis the most important buffers to external economic shocks have been wages and the employment level. In particular, Southern European countries and also Ireland had to regain their competitiveness in relation to the export-led Northern European countries (Hall 2014) through a real depreciation. The result has been a rearrangement of social inequalities in the EU and especially in the eurozone that can be 
summarized in terms of five trends: (1) polarization of European labour markets; (2) restructuring of the European centre-periphery relations due to the relative decline of Southern Europe and the continuing convergence of Eastern and Western Europe; (3) increasing national employment, income and health inequalities; (4) subjective Europeanization of inequalities; and (5) an impact of the EU on social inequalities. These five trends are summarized on the basis of the following chapters:

1. Overarching importance of the labour market as a buffer in the eurozone crisis. Among the variety of mechanisms by which a country can react to asymmetric economic shocks after the abolition of flexible exchange rates, the labour market was the most important 'shock absorber'. This explains the social crisis with very high and diverging unemployment levels (cf. Figures 1.1 and 1.2). While the income disparities in the enlarged EU remain broadly stable, the variation of regional and national unemployment rates has sharply increased since 2007 (Figure 1.5). The increasing variation of regional and national unemployment rates reflects the absence of alternative buffers for asymmetric economic shocks (Chapter 8). As a consequence, the level of poverty and persistent poverty risks are also growing, while the exit rates out of poverty are very low (Chapter 3 ).

2. Restructuring of European centre-periphery relations. The economic and income convergence between Northern and Southern Europe in the former $15 \mathrm{EU}$ Member States has come to an at least temporary halt, while the economic and income convergence continues between the currently 28 Member States of the EU - mainly due to a convergence between Western and Eastern Europe (Chapter 2). In sum, economic and income disparities in the EU remain stable because the increasing gap between the North and South is partially compensated by the East-West convergence (Figure 1.5). This overall stability, however, conceals the strong economic growth of many Eastern European countries (Poland, Lithuania, Latvia, Romania and Bulgaria) and the stagnation and decline of most Southern European countries.

3. Increasing social inequalities within the European nation-states. As previously mentioned, the gap between the social risks of higher- and low-skilled employees, healthy and chronically-ill employees, migrants and natives as well as younger and older persons has increased since the beginning of the crisis (Emmenegger et al. 2012: 373; Schwander and Häusermann 2013). Especially for younger persons, the fact of being temporarily employed becomes a serious social and unemployment risk - an indicator of the dualization of labour markets between insiders 


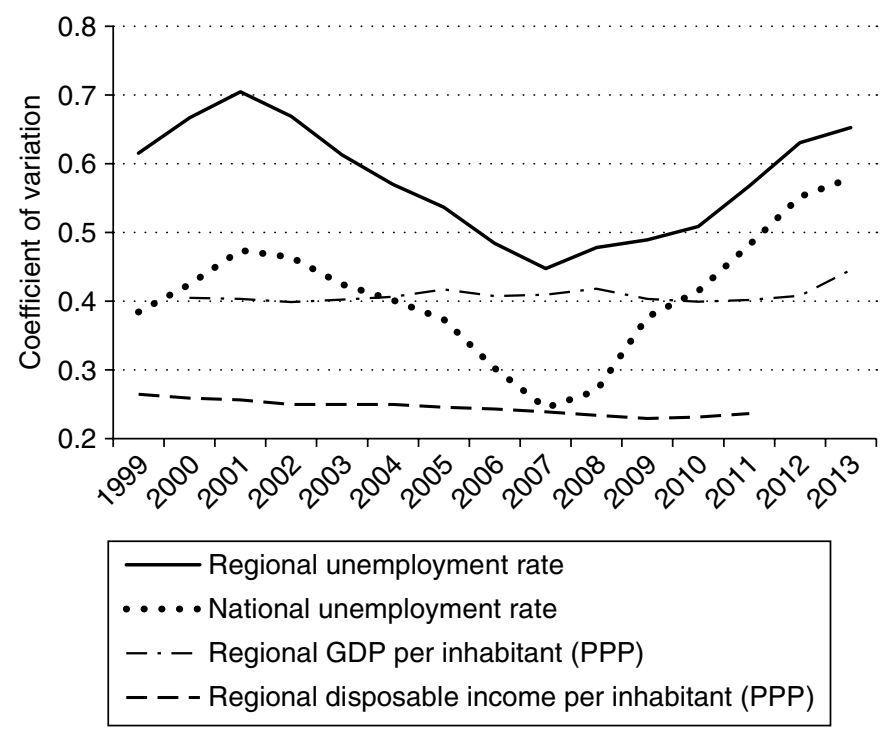

Source: Regional unemployment rates, gross domestic product (GDP) at current market prices and disposable income (PPS per inhabitant) by NUTS 2 regions [lfst_r_lfu3rt] and [nama_r_e2gdp] nama_r_ehh2inc. The coefficient of variation ratio has been calculated as the weighted standard deviation of the respective indicator to the weighted mean.

\section{Figure 1.5 Regional variation of economic, unemployment and income inequalities in the EU-27 (1999-2013)}

with permanent contracts and outsiders with temporary contracts (Chapters 4 and 6). Further indicators of the social dualization of nation-states are poverty rates and persistent poverty rates (Chapter 3 ). High poverty and deprivation rates often imply substandard living conditions and psycho-social stress stemming from the inability to afford basic items. These circumstances bring about an increased need for medical care for the deprived in particular, but also for the unemployed and chronically ill, who find their access to healthcare increasingly restricted due to costs and administrative hurdles to benefiting from free access (Chapter 7). However, a positive development is the continued increase of women in the labour markets (Chapter 5).

4. Increasing Europeanization of perceptions and opportunities. The crisis has eroded the trust of the European population in EU institutions (Chapter 8). This is also the result of the perceived Europeanization of social expectations and groups of reference (Chapter 2). Especially during the crisis, the economic situation is not only valued in relation to 
other compatriots, but increasingly also in relation to other Europeans, which explains the declining life and income satisfaction in poorer countries (Chapters 2 and 8).

5. Impact of the EU on social inequalities. The multi-level analyses in the following chapters show that in addition to individual and householdrelated factors, national context factors are important determinants of social inequalities. Examples are the influence of social security on the risk of poverty and social exclusion (Chapter 3). In addition, EU policies and their outcomes - especially common market regulations, monetary integration and European-wide regulation of public expenditures ('austerity'), but also activation policies (Chapter 4) - also have an impact on individual and household-related patterns of inequalities (for example on the provision of health services; cf. Chapter 7).

In sum, the dualization of labour markets, the reorganization of European centre-periphery relations, the perceived Europeanization of inequalities and the impact of EU decisions are major dimensions of the current social crisis in the EU. Due to the common market and monetary union, the EU has also become a political and administrative space that has a decisive impact on patterns of social inequalities - and this is increasingly also perceived by its citizens. Overall, the social and territorial differences of living conditions (income, poverty, deprivation, health status and general life satisfaction) have increased in Europe since the beginning of the financial, sovereign debt and economic crisis in 2008. The "double dualization' between advantaged and disadvantaged social groups and between Northern and Southern European countries has deepened during the crisis. After a decade of substantial capital flows to Southern Europe which have reduced economic divergences in Europe, social inequalities within and between the EU Member States are increasing in some dimensions and are threatening the social bases of European integration.

\subsection{STRUCTURE OF THE BOOK}

This book broadens the hitherto dominant national framework of inequality research by taking into account European factors that shape income inequality, access to employment opportunities and other social inequalities. By analysing the double dualization between the winners and losers of the crisis, the segmentation of labour markets and the perceived quality of life in Europe, this book contributes to a better understanding of the patterns and dynamics of inequality in an integrated Europe. Our analyses are in general based on micro-data provided by Eurostat - in particular the 
European Union Statistics on Income and Living Conditions (EU-SILC) ${ }^{1}$ and the Labour Force Survey - which are often combined with data on the national context and European policies in multi-level analyses. These data cover both some years before and the years of the eurozone crisis.

In Chapter 2, Martin Heidenreich specifies the previously explained international, supranational and transnational understandings of the Europeanization of inequalities for the case of income inequality. Firstly, it is shown that the move towards increasing national income inequalities has been reversed, especially in the former 15 EU Member States. Secondly, national and regional patterns of income inequality are also shaped by the growing economic integration at the European level. Thirdly, the subjective perception of economic stress is not only shaped by national frames of reference but also by transnational ones.

In Chapter 3, Cathrin Ingensiep discusses the evolution of persistent poverty and its national determinants during the economic and financial crisis. She asks which institutional factors prevent long-term poverty. In the analysis based on EU-SILC longitudinal data, it is shown that persistent poverty mostly affects the already disadvantaged social groups. Social expenditure - but not low national unemployment levels - is essential for preventing long episodes of poverty. Temporary and permanently poor people are affected differently by these national factors. While a higher unemployment rate does not alter the risk of becoming long-term poor, growing social expenditure reduces this risk. Hence, during the crisis, job security cannot be seen as a safeguard against long-term poverty, while social expenditure protects people from persistent poverty.

In Chapter 4, Martin Heidenreich discusses the changing social distribution of unemployment and long-term unemployment risks during the eurozone crisis. These risks are interpreted as the result of three different, overlapping forms of labour market segmentation: firstly, the institutionally stabilized polarization between labour market insiders and outsiders; secondly, the occupational dualization of high- and low-skilled employees and occupations; and, thirdly, the marginalization of disadvantaged social groups. It can be shown that (long-term) unemployment risks especially increase for low-skilled people and occupations, single parents, migrants and ill people. Women, older and permanently employed people are relatively less affected by short-term unemployment but are more affected by long-term unemployment. Hence, the current crisis strengthens the occupational and social dualization of labour markets, endangering the inclusiveness and long-term growth potential of the European economy and societies.

In Chapter 5, Martin Heidenreich discusses whether the financial, economic and sovereign debt crisis has also had major effects on the 
employment and earnings conditions of women. On the basis of macroand micro-data, this chapter discusses whether this crisis and the austerity policies in the countries most affected by the crisis have had a negative effect on the employment and wage conditions of women (austerity), whether the inclusion of women in the labour market has continued, and whether the dualization of the labour markets has also affected the employment and earnings situation of women, and in which dimensions. The austerity hypothesis can be generally refuted. Secondly, during the crisis, the shift towards more inclusive employment patterns has continued. The gender gaps in employment and unemployment rates have continued to shrink, especially in Southern European countries, which have been the bulwark of the male breadwinner model in Europe. Particularly during the crisis, high unemployment rates have contributed to the erosion of traditional gender relations. Thirdly, the employment profiles of women clearly differ from their male counterparts. Employed women are generally more highly qualified, mostly employed in the service sector, and are overrepresented in atypical and low-paid jobs. This indicates a particular pattern of labour market inclusion which is based on a dualization between low- and high-skilled women - some women are the winners of the eurozone crisis, while others are the losers - and also of the continuing inclusion of women in the labour market.

In Chapter 6, Christian Reimann analyses the development of atypical employment relationships and their individual and national determinants from 2002 to 2013 on the basis of the European Labour Force Survey. Labour market reforms have increased temporary employment rates in Europe since the 1970s. This development led to a dualization between permanently employed insiders and temporarily employed outsiders. However, national institutions as well as economic and labour market structures remain very different. The thesis of this chapter is that the insider-outsider divide increasingly depends on individual characteristics such as gender, age and educational attainment, while national particularities are losing their importance in determining the risk of being temporarily employed. It is shown that national institutions and structures have lost their explanatory power, particularly during the years before the crisis. This de-territorialization of social inequalities can be interpreted as an indicator of Europeanization processes affecting the labour market segmentation. With the onset of the crisis in 2008/2009, however, the situation changed. National institutional factors such as employment protection, unemployment rate and economic growth once again influence the risk of temporary employment - an indicator of the renationalization of employment policies.

In Chapter 7, Sabine Israel adopts a transnational perspective to 
assess the health consequences of the eurozone crisis and its austerity policies for the population in the European peripheral countries. Physical, psycho-social and medical health determinants which commonly explain poor health among people of low income are included in the analysis in order to describe the diffusion of adverse social conditions. On the basis of EU-SILC, two sets of disadvantaged countries are compared from 2006/2007 to 2011/2012: West European countries which are subject to Economic Adjustment Programmes (EAPs), and East European countries which are subject to Balance of Payment Programmes (BoPs). It is shown that deprivation, arrears and access to healthcare are worsening in the majority of the peripheral countries. The BoP countries Latvia and Romania display increased barriers to healthcare, while mortgage problems are turning into a problem in Ireland and Greece. Moreover, deprivation affected more than three-fifths of the population in Greece, Hungary and Latvia in 2011/2012. While the sharpest increase in adverse social determinants can be observed in the lower-income quintiles, self-perceived poor health is mostly diffused among the people in the lowest - but also in the second- and third-income - quintile, bringing the social gradient in health to its demise. This surprising result can be explained by the relative improvement in the social position of the poorest, but also by means-tested exemptions from payments of services such as healthcare, which shift the cost burden towards higher-income quintiles.

In Chapter 8, Franziska Buttler starts from the observation that postwar Europe is characterized by new transnational interrelations. European Integration opened up new opportunity structures that may help individuals to achieve a certain standard of living and to deal with unpleasant life events. This raises the question of whether processes of horizontal Europeanization have opened up new possibilities and enriched opportunities. It can be shown that individuals who make transnational experiences are more satisfied with their lives than other people. A similar relationship can be observed on the country level as well. Nation-states which are open towards other European countries in the social domains of tourism, working abroad, immigration and European higher-education exchange increase the chances of higher individual life satisfaction. Hence, social transnational interrelations are beneficial for the utilization of resources which help to deal with problematic occurrences in life, especially in times of crisis.

In Chapter 9, Jenny Preunkert discusses the question of whether the previously discussed evolution of social inequalities - especially the high (youth) unemployment rates and the vast poverty, social exclusion and health problems - is also shaped by the political reaction to the sovereign debt crisis. She discusses the question of whether the conditions imposed 
by the eurozone bailout funds have contributed to the social problems faced by Southern European Member States and Ireland. In addition to an economic dimension, do the eurozone bailout funds also have a social dimension? Are the previously mentioned social problems relevant political issues in the management of the European crisis? The analysis shows that the social problems have been recognized within the European crisis policy, yet to this day social security systems have been mainly treated as a cost factor that has to be reduced. Additional social assistance has only been demanded for specific disadvantaged social groups.

\section{ACKNOWLEDGEMENTS}

This book is the result of a research project on the Europeanization of social inequalities, which was supported by a grant from the German Research Foundation (DFG) (grant no. HE 2174/12-1). The research took place at the University of Oldenburg in the context of the DFGfunded research unit 'Horizontal Europeanization' (FOR 1539). The authors would like to thank their fellow authors for their suggestions and comments, Eckard Kämper (DFG) and the scientific advisory board (Bernhard Ebbinghaus, Max Haller, Jo Reichertz, Peter Wagner, Anja Weiß and Theresa Wobbe) for their active and benevolent support of our research group, Isolde Heyen and Kerstin Zemke for their invaluable administrative support, and Natalie Chandler for her linguistic revision of our articles.

\section{NOTE}

1. EU-SILC (Statistics on Income and Living Conditions) is an EU-wide survey on income, poverty and living conditions in Europe which started in 2004, initially in 13 countries and by 2013 in 32 countries (EU-28 plus Iceland, Switzerland, Norway and Serbia). Data for Bulgaria and Romania have been available since 2007, data for Malta since 2008, and data for Croatia since 2010. EU-SILC is not a common survey, but tries to unify and harmonize the concepts employed - for example the concept of disposable income - and the survey methods. It is based on uniform definitions and methodological minimum standards. It consists of a household questionnaire and an individual questionnaire for household members aged 16 years and over. It covers in detail the income and material living conditions of households in Europe. Both with regard to sampling and data collection, the SILC data are still subject to considerable problems. Despite the methodological problems in terms of representativeness, accuracy, comparability and coherence, the EU-SILC data are currently the only available data source for comparative international and supranational analyses of income and living conditions in the EU. 


\section{REFERENCES}

Alderson, A.S. and F. Nielsen (2002), 'Globalization and the Great U-Turn. Income Inequality Trends in 16 OECD Countries', American Journal of Sociology 107 (5): 1244-1299.

Armingeon, K. and B. Ceka (2013), 'The Loss of Trust in the European Union During the Great Recession Since 2007: The Role of Heuristics from the National Political System', European Union Politics, doi: 10.1177/1465116513495595 (online).

Beck, U. (2007), 'Beyond Class and Nation: Reframing Social Inequalities in a Globalizing World', The British Journal of Sociology 58 (4): 679-705.

Beckfield, J. (2006), 'European Integration and Income Inequality', American Sociological Review 71 (6): 964-985.

Beckfield, J. (2009), 'Remapping Inequality in Europe', International Journal of Comparative Sociology 50 (5-6): 486-504.

Blyth, M. (2013), Austerity: The History of a Dangerous Idea, Oxford: Oxford University Press.

Braun, D. and M. Tausendpfund (2014), 'The Impact of the Euro Crisis on Citizens' Support for the European Union', Journal of European Integration 36 (3): 231-245.

Brenner, N. (2001), 'The Limits to Scale? Methodological Reflections on Scalar Structuration Progress', Human Geography 25 (4): 591-614.

Castles, F.G., S. Leibfried, J. Lewis, H. Obinger and C. Pierson (2010), The Oxford Handbook of the Welfare State, Oxford: Oxford University Press.

De Grauwe, P. (2014), Economics of Monetary Union. 10th revised edition, Oxford: Oxford University Press.

Delhey, J. and U. Kohler (2006), 'From Nationally Bounded to Pan-European Inequalities? On the Importance of Foreign Countries as Reference Groups', European Sociological Review 22: 125-140.

Emmenegger, P., S. Häusermann, B. Palier and M. Seeleib-Kaiser (eds) (2012), The Age of Dualization: The Changing Face of Inequality in Deindustrializing Societies, Oxford: Oxford University Press.

Fahey, T. (2007), 'The Case for an EU-wide Measure of Poverty', European Sociological Review 23 (1): 35-47.

Featherstone, K. and C.M. Radaelli (eds) (2003), The Politics of Europeanization, Oxford: Oxford University Press.

Ferrera, M. (2003), 'European Integration and National Social Citizenship', Comparative Political Studies 36 (6): 611-652.

Fligstein, N. (2008), Euroclash, Oxford: Oxford University Press.

Fligstein, N. and A. Stone Sweet (2002), 'Constructing Polities and Markets: An Institutionalist Account of European Integration 1', American Journal of Sociology 107 (5): 1206-1243.

Friedman, M. (1997), Why Europe Can't Afford the Euro-The Danger of a Common Currency, The Times, 19 November. Accessed 8 October 2015 at www.projectsyndicate.org/commentary/the-euro--monetary-unity-to-political-disunity.

Gallie, D. and S. Paugam (eds) (2000), Welfare Regimes and the Experience of Unemployment in Europe, Oxford: Oxford University Press.

Geiger, T. (1932), Die soziale Schichtung des deutschen Volkes. Soziographischer Versuch auf statistischer Grundlage, Stuttgart: Enke.

Gerhards, J. and H. Lengfeld (2015), European Citizenship and Social Integration in the European Union, London and New York: Routledge. 
Giddens, A. (2014), Turbulent and Mighty Continent: What Future for Europe, Cambridge: Polity.

Hall, P.A. (2014), 'Varieties of Capitalism and the Euro Crisis', West European Politics 37 (6): 1223-1243.

Heidenreich, M. (2003), 'Regional Inequalities in the Enlarged Europe', Journal of European Social Policy 13 (4): 313-333.

Heidenreich, M. and C. Wunder (2008), 'Patterns of Regional Inequality in the Enlarged Europe', European Sociological Review 24 (1): 19-36.

Hooghe, L. and G. Marks (2009), 'A Postfunctionalist Theory of European Integration', British Journal of Political Science 39 (1): 1-23.

Kangas, O.E. and V. Ritakallio (2007), 'Relative to What? Cross National Pictures of European Poverty Measured by Regional, National and European Standards', European Societies 9: 119-145.

Kenworthy, L. (2004), Egalitarian Capitalism, New York: Russell Sage Foundation.

Kriesi, H., E. Grande, R. Lachat, M. Dolezal, S. Bornschier and T. Frey (2006), 'Globalization and the Transformation of the National Political Space: Six European Countries Compared', European Journal of Political Research 45 (6): 921-956.

Mau, S. and J. Mewes (2012), 'Horizontal Europeanisation in Contextual Perspective: What Drives Cross-border Activities Within the European Union?', European Societies 14 (1): 7-34.

Mau, S., J. Mewes and N.M. Schöneck (2012), 'What Determines Subjective Socioeconomic Insecurity? Context and Class in Comparative Perspective', SocioEconomic Review 10 (4): 655-682.

Milanovic, B. (2013), 'Global Income Inequality in Numbers: In History and Now', Global Policy 4 (2): 198-208.

Moravcsik, A. (1998), The Choice for Europe: Social Purpose and State Power from Messina to Maastricht, Ithaca, NY: Cornell University Press.

OECD (2011), Divided We Stand: Why Inequality Keeps Rising, Paris: OECD.

OECD (2015), In It Together: Why Less Inequality Benefits All, Paris: OECD.

Radaelli, C. (2003), 'The Europeanization of Public Policy', in K. Featherstone and C. Radaelli (eds), The Politics of Europeanization, Oxford: Oxford University Press, pp. 27-56.

Rokkan, S. (1999), State Formation, Nation-building, and Mass Politics in Europe, Oxford: Oxford University Press.

Schwander, H. and S. Häusermann (2013), 'Who Is In and Who Is Out? A Riskbased Conceptualization of Insiders and Outsiders', Journal of European Social Policy 23 (3): 248-269.

Shambaugh, J.C. (2012), 'The Euro's Three Crises', Brookings Papers on Economic Activity 44 (1): 157-211.

Smith, A.D. (1983), 'Nationalism and Classical Social Theory', British Journal of Sociology 34 (1): 19-38.

Whelan, C.T. and B. Maître (2009), 'Europeanization of Inequality and European Reference Groups', Journal of European Social Policy 19 (2): 117-130.

Wilkinson, R.G. and K. Pickett (2009), The Spirit Level: Why More Equal Societies Almost Always Do Better, London: Allen Lane. 